\title{
$\mathrm{Fe}-0.4 \mathrm{C}$ 合金の強磁場中等温フェライト变態に おける組織配向*
}

\author{
Xin Jiang Hao ${ }^{1}$ 大塚秀幸 ${ }^{1}$ 和田 仁 $^{2}$ \\ 1物質・材料研究機構強磁場研究センター \\ 2 東京大学大学院新領域創成科学研究科 \\ J. Japan Inst. Metals, Vol. 69, No. 4 (2005), pp. 368-372 \\ (C) 2005 The Japan Institute of Metals

\section{Structural Elongation and Alignment in an Fe-0.4C Alloy by Isothermal Ferrite Tansformation in High Magnetic Fields}

\author{
Xin Jiang Hao ${ }^{1}$, Hideyuki Ohtsuka ${ }^{1}$ and Hitoshi Wada ${ }^{2}$ \\ ${ }^{1}$ Tsukuba Magnet Laboratory, National Institute for Materials Science, Tsukuba 305-0003 \\ ${ }^{2}$ Graduate School of Frontier Sciences, The University of Tokyo, Kashiwa 277-8561
}

Structural elongation and alignment in an $\mathrm{Fe}-0.4 \mathrm{C}$ alloy isothermally transformed in high magnetic fields has been studied by quantitative microscopy analysis. It has been already reported by the authors that an elongated and aligned structure is obtained during continuous cooling as far as some conditions are satisfied. It is shown in this paper that an elongated and aligned two-phase structure is formed in high magnetic fields by isothermal ferrite transformation both below and above Curie temperature. To clarify if the elongated structure is formed in the nucleation stage or growth stage, transformation behavior in magnetic fields has been investigated and it was found that equiaxed ferrite grains nucleate randomly at austenite grain boundaries and they become elongated by preferred growth along the direction of applied magnetic field. Effects of isothermal transformation temperature on the degree of elongation has been studied. Below Curie temperature, the degree of elongation increases with increasing transformation temperature, whereas it decreases above Curie temperature. Small chemical driving force for ferrite precipitation and large magnetization of ferrite in high magnetic fields favor the formation of elongated structure.

(Received December 17, 2004; Accepted February 16, 2005)

Keywords: structural elongation and alignment, ferrite transformation, high magnetic field, quantitative microscopy, isothermal transformation

\section{1. 緒言}

近年, 強磁場を発生する超伝導マグネットの急速な発達に 伴い，鉄系合金に打けるマルテンサイト1)・フェライ $ト^{2-11)}$ ・パーライト12)変態や再結晶 ${ }^{13-17)}$ などの固相/固相変 態に対して強磁場の影響があることが明らかになってきた. 磁場効果の中でも組織の伸長・配向は磁場中で変態した組織 に特有のものである. 大塚ら ${ }^{4)}$ は初めて強磁場中での徐冷に よりオーステナイトからフェライトへの変態に打いて伸長 . 配向した組織が形成されることを報告した．さらに組織的な 伸長の度合いを定量的に表す方法について示した6). 徐冷に より形成される組織の伸長の度合いは印加磁場の強度ととも に上昇する.フェライトの配向については丸太ら ${ }^{10)}$ ，执よ び下斗米ら11)によっても報告されているが，彼らは伸長し た二相組織を形成するためには前加工と磁場中での変態の両 方が必要であると述べているが，本研究および我々のこれま での研究4,6,7)からも加工しなくても伸長組織は得られる.

\footnotetext{
* Mater. Trans. 44(2003) 2532-2536に掲載
}

本研究においては，(1)徐冷によりフェライトが伸長・配向 することをすでに明らかにしたが，等温保持でも伸長・配向 するか，(2)フェライトのキュリー温度以上でもフェライトは 伸長・配向するか，(3)伸長組織は核生成と成長のいずれの段 階で形成されるのか，(4)伸長の度合いは変態温度によりどの ように変化するか，を明らかにすることを目的とする。

\section{2. 実 験 方 法}

本研究で用いた合金は $\mathrm{Fe}-0.4 \mathrm{C}$ 合金で，真空溶解により 作製した。 その化学組成は $\mathrm{Fe}-0.41 \mathrm{C}-0.08 \mathrm{Si}-0.003 \mathrm{Al}$ $(\operatorname{mass} \%)$ で, サーモカルクにより計算した $\mathrm{A}_{\mathrm{e} 3}$ 温度は $785^{\circ} \mathrm{C}$ である. 熱間圧延後, $5 \mathrm{~mm} \times 5 \mathrm{~mm} \times 1 \mathrm{~mm}$ の試料を 切り出して口径 $100 \mathrm{~mm}$ の室温空間を持つヘリウムフリー 型の超伝導マグネットに挿入した真空加熱炉中にセットし た．磁場は $5 \mathrm{~mm} \times 5 \mathrm{~mm}$ の面に垂直に印加され，27 分間で $10 \mathrm{~T}$ に励磁した後オーステナイト化, 等温保持, 室温への 冷却, などの熱処理をすべて終了してから0 T に降磁し た. 試料は磁場中心に固定されるため試料への磁化力は無視 できる. 熱処理としては $1000^{\circ} \mathrm{C} て ゙ 15$ 分間オーステナイト 
化後 $50^{\circ} \mathrm{C} / \mathrm{min}$ で $740 \sim 785^{\circ} \mathrm{C}$ の間の種々の温度へ冷却して 等温保持し, フェライト変態させた後へリウムガスにより室 温まで冷却した。ヘリウムガスにより，試料は $1000^{\circ} \mathrm{C}$ から $400^{\circ} \mathrm{C}$ まで約 40 秒で冷却できる. 熱処理した試料は研磨, $3 \%$ ナタールによる腐食のあと光学顕微鏡により組織観察 した. 観察面は磁場印加方向に平行な面で, 各組織写真に磁 場印加方向を矢印で示した。

\section{3. 実 験 結 果}

\section{1 等温フェライト変態に及ぼす磁場の影響}

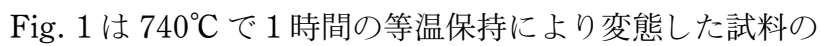
組織を示す。この温度はフェライトのキュリー温度 $\left(770^{\circ} \mathrm{C}\right)$ より低い温度で，(a)は無磁場，（b）は $10 \mathrm{~T} の$ 磁場中で熱処 理した. 白い部分は等温保持中にオーステナイトから生成し たフェライトである. 黒い部分は最後のへリウムガスによる 冷却中にオーステナイトがパーライトに変態した部分であ る、無磁場ではほとんどのフェライト粒は等軸であるが，磁 場を印加すると組織は異なるものになる。まず，フェライト の量が増える. 次に, 多くのフェライト粒は伸長した形状に なり，その長軸方向と磁場印加方向が平行なものが多い.

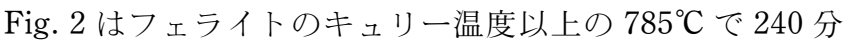

間等温保持した場合の組織である. $785^{\circ} \mathrm{C}$ はこの合金の $\mathrm{A}_{\mathrm{e} 3}$ 温度であるため変態の駆動力はゼロであり，無磁場の場合 (a) はフェライト粒は観察されない。旧オーステナイト粒界 は最後の室温への急冷中に薄いフィルム状にフェライトが析 出したため明瞭に観察できる.（b)では等温保持中にオース テナイト粒界から生成した大きなフェライト粒が観察される が，磁場印加方向に平行に伸長している，粒界に生成した薄 いフィルム状のフェライトについては無磁場と磁場印加で差 が見られない. Fig. 1 および 2 からフェライトのキュリー温 度より高温でも低温でもフェライト变態挙動や組織は $10 \mathrm{~T}$ の強磁場により大きく影響される事が分かる，すなわち，変 態は促進され, 変態率も増加する $2,3,5,8,9)$. これは, 熱力学的 な計算により示されるように ${ }^{5,8,9)} \mathrm{A}_{\mathrm{e} 3}$ 温度が磁場印加により 上昇するため同じ温度であれば磁場印加のため，より大きな フェライト変態の駆動力が与えられるからである. 比較的遅 い冷却速度の場合にフェライト粒が伸長・配向して生成する

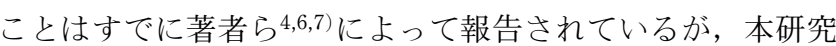
では等温保持においても，しかもフェライトのキュリ一温度 以上でも以下でも同じような伸長・配向組織が得られること が明らかになった．このような伸長・配向組織は磁場印加に より得られる独特の組織である. その生成メカニズムは明ら かではないが，次節においてフェライト粒の核生成・成長と
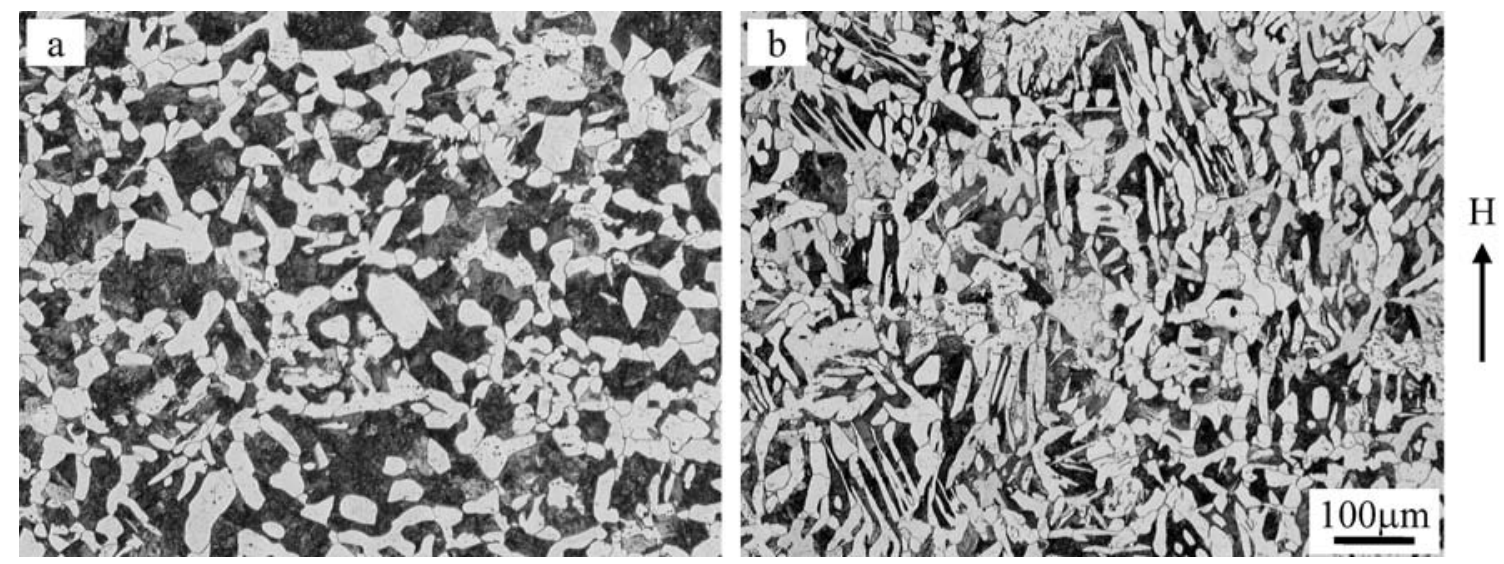

Fig. 1 Microstructures of $\mathrm{Fe}-0.4 \mathrm{C}$ alloy heat treated below Curie temperature of ferrite. Specimens were austenitized at $1000^{\circ} \mathrm{C}$ for 15 min and transformed at $740^{\circ} \mathrm{C}$ for 1 hour without (a) or with a magnetic field of $10 \mathrm{~T}$ (b), followed by helium gas quenching.
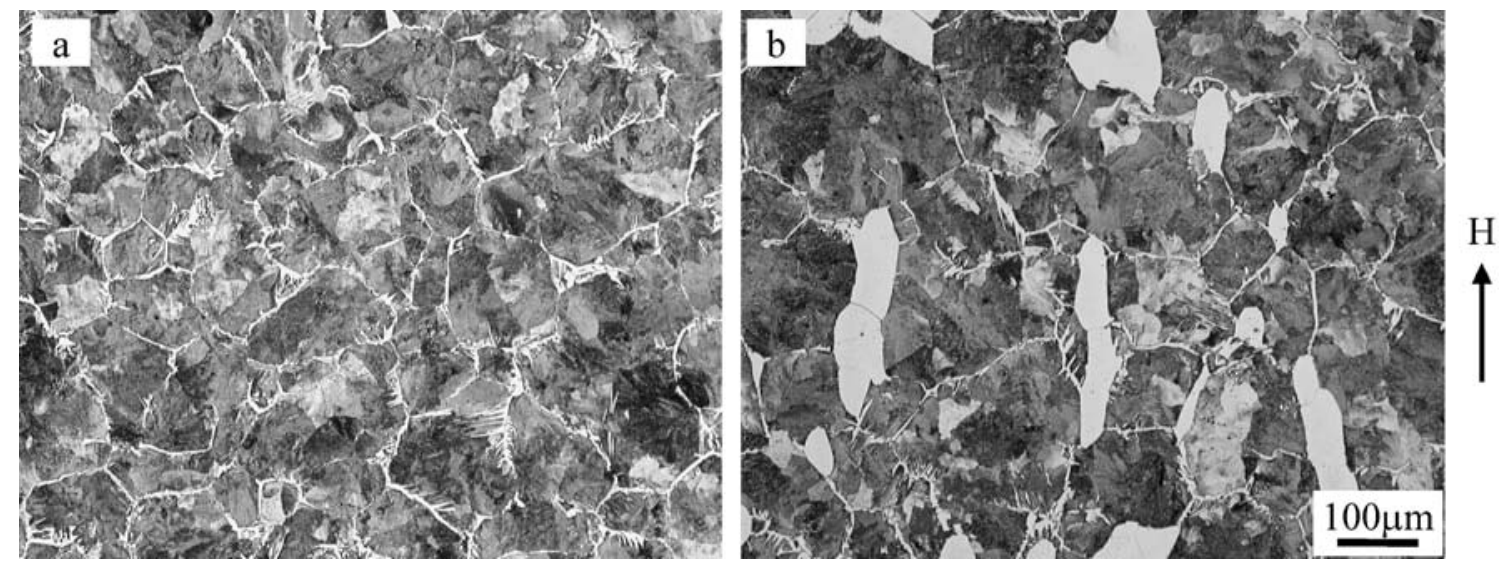

Fig. 2 Microstructures of $\mathrm{Fe}-0.4 \mathrm{C}$ alloy heat treated above Curie temperature of ferrite. Specimens were austenitized at $1000^{\circ} \mathrm{C}$ for $15 \mathrm{~min}$ and transformed at $785^{\circ} \mathrm{C}$ for $240 \mathrm{~min}$ without (a) or with a magnetic field of $10 \mathrm{~T}$ (b), followed by helium gas quenching. 
関係づけて考察する.

\section{2 磁場中におけるフェライト粒の核生成·成長}

Fig. 3 は, $10 \mathrm{~T}$ の磁場中で $785^{\circ} \mathrm{C}$ でそれぞれ (a) 10 ，(b) 20, (c) 30, (d) 240 分間等温保持した場合の組織を光学顕微 鏡で観察したものである。ほとんどのフェライト粒はオース テナイト粒界, 特に粒界三重点に生成する。変態初期 (a)に おいてはフェライト粒は等軸で試料全体としてはランダムに 分布している. 保持時間が 20 分(b)，30 分(c) と増加するに つれてフェライトの量は増加し，いくつかのフェライト粒は 磁場印加方向に伸長し始める. 240 分 $(d)$ の等温保持ではほ とんどのフェライト粒が伸長し, いくつかの粒は磁場印加方 向に連結して生成し, 組織配向する.

組織的な伸長の度合い, $\omega$ は直線とフェライト/オーステ ナイト界面の交点の数を数えることにより求められ ${ }^{6)}$, 次式 で表せる18).

$$
\omega=\left(N_{\perp}-N_{\|}\right) /\left(N_{\perp}+0.571 N_{\|}\right)
$$

ここで， $N_{\perp}$ と $N_{\|}$はそれぞれ直線と磁場印加方向が垂直, 平行な場合の交点の数である. Fig. 4 は測定した組織的な伸 長の度合いと等温変態時間の関係を示し，伸長の度合いは変 態時間とともに強くなる. 変態初期においては伸長の度合い は弱いが，その後变態時間とともに急激に増加し，やがて飽 和していくことが分かり，すでに Fig. 3 について述べた実 験事実とも一致する，以上のように，伸長・配向した組織は 核生成の段階ではなく，成長段階で形成されていくことが分
かる。

\section{3 組織伸長の度合いに及ぼす変態温度の影響}

Fig. 5 は (a)キュリー温度の $770^{\circ} \mathrm{C}$, (b) $750^{\circ} \mathrm{C}$ で, いずれ も 30 分間, $10 \mathrm{~T}$ の磁場中で等温保持したときの組織を光学 顕微鏡で観察したものである。（a）に示すように，キュリー 温度ではフェライト粒は伸長し，その多くは磁場印加方向之 平行に連結して配向している，一方，（b）に示すように変態 温度が $750^{\circ} \mathrm{C}$ に下がると変態量は増加し, フェライト粒径 は小さくなる．核生成の駆動力が増加するためオーステナイ

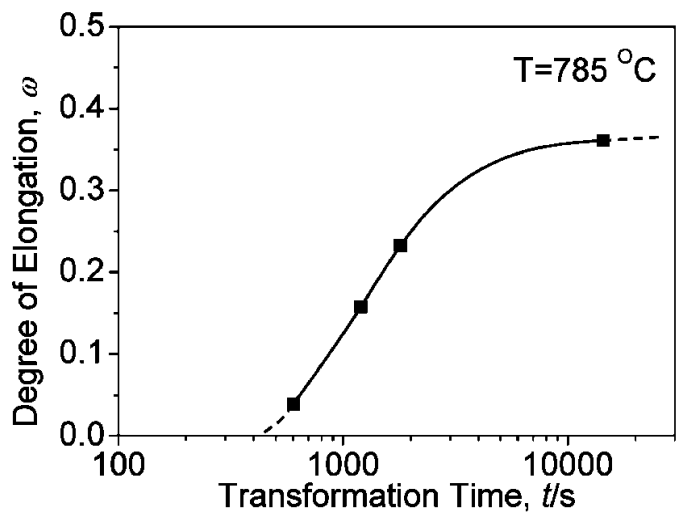

Fig. 4 Degree of elongation as a function of transformation time.

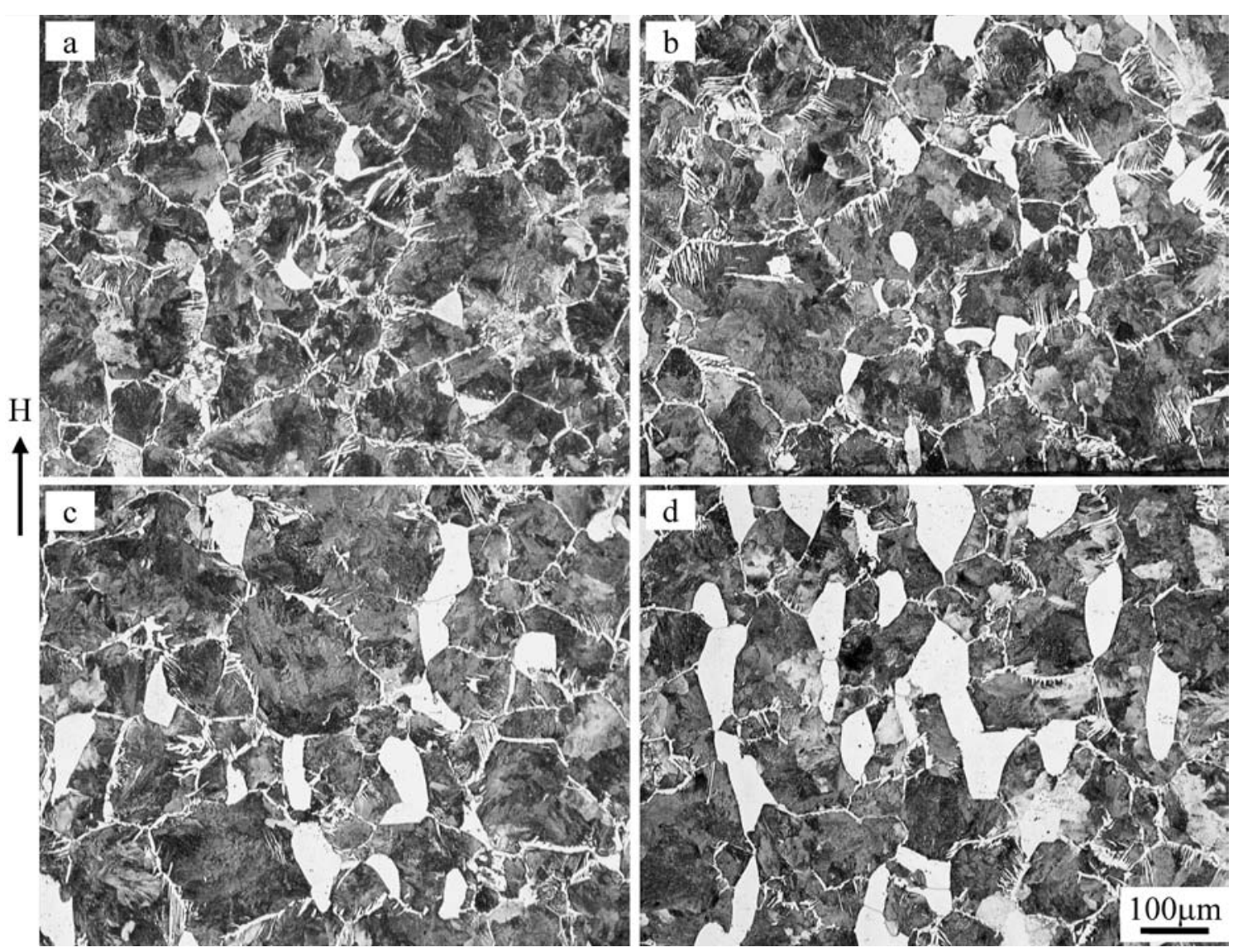

Fig. 3 Microstructures of $\mathrm{Fe}-0.4 \mathrm{C}$ alloy heat treated in a magnetic field of $10 \mathrm{~T}$. Specimens were austenitized at $1000^{\circ} \mathrm{C}$ for $15 \mathrm{~min}$ and transformed at $785^{\circ} \mathrm{C}$ for (a) $10 \mathrm{~min}$, (b) $20 \mathrm{~min}$, (c) $30 \mathrm{~min}$ and (b) $240 \mathrm{~min}$. 


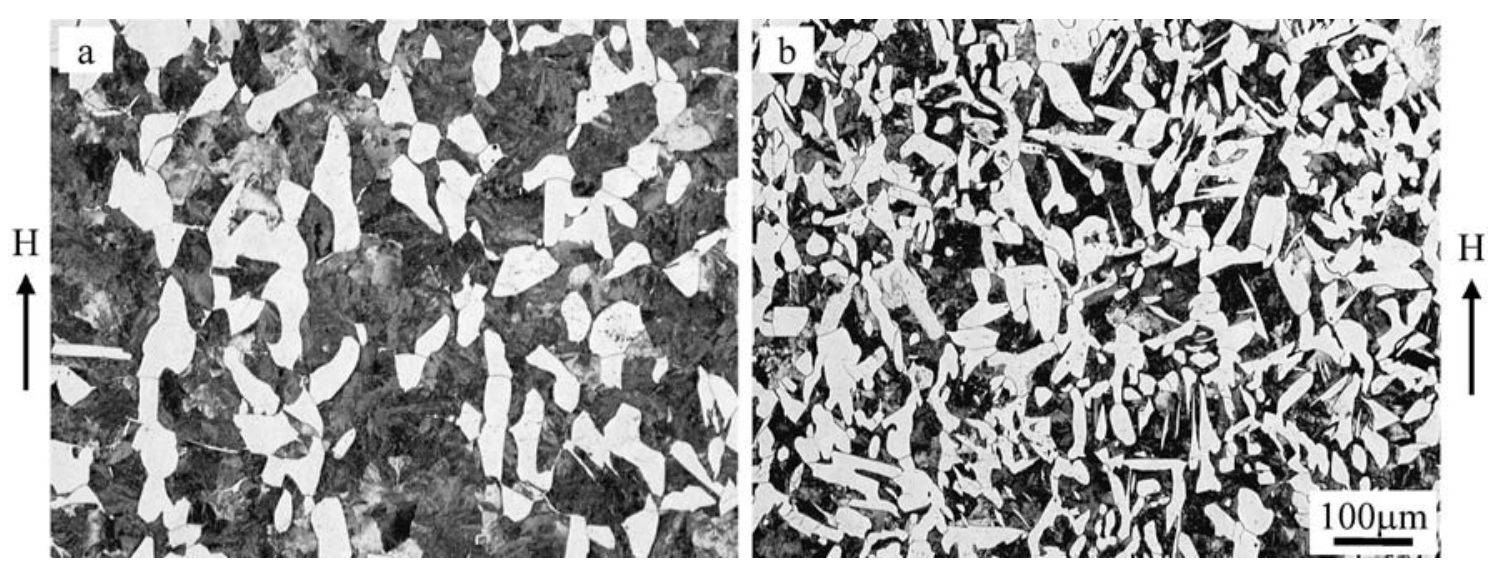

Fig. 5 Microstructures of $\mathrm{Fe}-0.4 \mathrm{C}$ alloy heat treated in a magnetic field of $10 \mathrm{~T}$. Specimens were austenitized at $1000^{\circ} \mathrm{C}$ for $15 \mathrm{~min}$ and transformed at (a) $770^{\circ} \mathrm{C}$ and (b) $750^{\circ} \mathrm{C}$ for $30 \mathrm{~min}$.

ト粒界のみならず，粒内もフェライトの核生成場所となって いる．棒状，或いは針状のフェライトも生成するが，磁場印 加方向と平行ではないものもある. 等温保持時間が 30 分の 場合, 組織伸長の度合と変態温度の関係は Fig. 6 のように なる，組織伸長の度合いは変態温度が低くなるほど強くな り, キュリー温度付近で最も大きくなり, その後変態温度の 低下とともに弱くなっていく.

フェライト粒の伸長・配向の原因はまだ明らかではない が，フェライト粒が磁場印加方向に伸長することによりフェ ライト粒の反磁場が小さくなり, 系の自由エネルギーが低下 することが予想される ${ }^{4)}$ 。すでに示したように，磁場印加方 向への優先成長によりフェライト粒は伸長する。しかしなが ら, 成長速度はフェライト/オーステナイト界面エネル ギー, フェライト変態の駆動力, 反磁場効果や炭素の拡散な ぞ，色々な因子に左右されるためフェライト粒伸長の微視的 なメカニズムを説明することは難しい。これまでフェライ ト/オーステナイト界面エネルギーに及ぼす磁場の影響につ いては報告がない，炭素の拡散に及ぼす磁場効果については 連川ら ${ }^{19)}$ の論文があり，オーステナイト中で炭素の拡散速 度は磁場印加により遅くなることを報告しているが，磁場印 加方向とは無関係である ${ }^{20)}$. 従って本研究における磁場印 加方向への優先的な成長は炭素の拡散に及ぼす磁場印加の効 果では説明できない，そこで反磁場効果と変態駆動力につい て考察する。

フェライト粒中の反磁場 $H_{\mathrm{d}}$ は次式で表せる.

$$
H_{\mathrm{d}}=\left(N_{\mathrm{d}} \cdot M\right) / \mu_{0}
$$

ここで， $N_{\mathrm{d}}$ は反磁場係数でフェライト粒の形状に依存する. $M$ はフェライトの磁化， $\mu_{0}$ は真空の透磁率である. フェラ イトの磁化， $M$ が大きいほど， $N_{\mathrm{d}}$ が小さくなることにより 反磁場エネルギーが下がるのでフェライト粒は伸長する. $10 \mathrm{~T}$ の磁場中に打ける純鉄の磁化はワイスの分子場理論を 用いて計算した5)。その結果，キュリ一温度以上に抢いても 磁化は存在し5,8,9) $785^{\circ} \mathrm{C}$ における磁化は約 $0.245 \mathrm{Mo}(\mathrm{Mo}=$ $1.74 \times 10^{6} \mathrm{~A} / \mathrm{m}$ で $0 \mathrm{~K}$ に抢ける純鉄の飽和磁化)，キュリー 温度では約 $0.287 \mathrm{Mo}$ へ増加する。キュリー温度以下では 磁化は自発磁化と磁場誘起による磁化から成り， $760^{\circ} \mathrm{C}$ では 磁化は $0.313 \mathrm{Mo}, 740^{\circ} \mathrm{C}$ では $0.367 \mathrm{Mo} へ$ と増加する。従っ

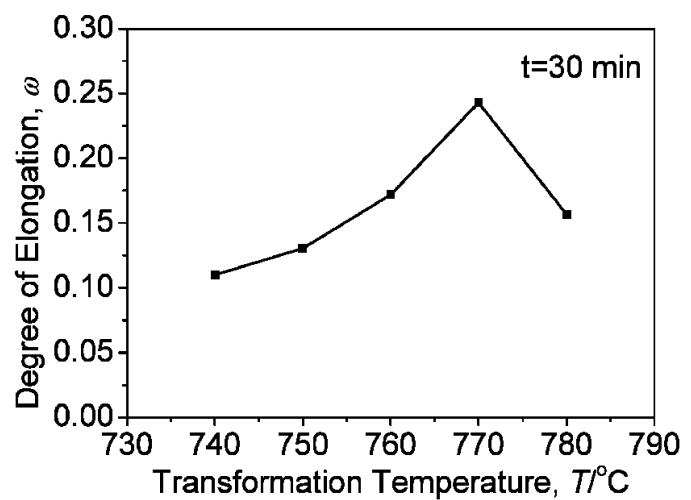

Fig. 6 Degree of elongation as a function of transformation temperature.

て組織伸長の度合いは温度が低くなるほど強くなる。一方駆 動力については，冷却速度が小さくなるほど組織伸長の度合 いは強くなるという実駼結果 4,7 )から，変態駆動力が小さく なるほど組織伸長の度合いは強くなると考えられる。すなわ ち変態温度が低くなるほど変態駆動力は大きくなり，組織伸 長の度合いは弱くなる，以上のことから，反磁場効果を考え ると温度が低くなるほど伸長の度合いが強くなり，変態駆動 力の効果を考えると温度が低くなるほど伸長の度合いは弱く なる，という二つの効果の兼ね合いでフェライト粒の伸長の 度合いは決まると考えられる。

\section{4. まと め}

(1) $\mathrm{Fe}-0.4 \% \mathrm{C}$ 合金において，強磁場中では等温保持によ っても，またフェライトのキュリー温度より高温でも低温で も組織伸長・配向が観察された。

(2) 変態初期に怙いては等軸フェライトがランダムにオー ステナイト粒界に生成するが，その後成長段階に打いて磁場 印加方向に伸長していく.

（3）組織伸長の度合いは変態温度に依存し，キュリー温度 以下では変態温度の上昇とともに強くなるが，キュリー温度 以上では弱くなる.

（4）変態駆動力が小さいほど，またフェライトの磁化が大 
きいほど組織伸長・配向の度合いは強くなり，その温度依存 性は反磁場効果と変態駆動力の兼ね合いで決まる.

\section{文献}

1) T. Kakeshita, K. Kuroiwa, K. Shimizu, T. Ikeda, A. Yamagishi and M. Date: Mater. Trans., JIM 34(1993) 423-428.

2) Y. Xu, H. Ohtsuka and H. Wada: Journal of the Magnetics Society of Japan 24(2000) 655-658.

3) Y. Xu, H. Ohtsuka and H. Wada: Trans. Mater. Res. Soc. Japan $25(2000)$ 505-508.

4) H. Ohtsuka, Y. Xu and H. Wada: Mater. Trans., JIM 41 (2000) 907-910.

5) J.-K. Choi, H. Ohtsuka, Y. Xu and W.-Y. Choo: Scr. Mater. $43(2000)$ 221-226.

6) X. J. Hao, H. Ohtsuka, P. DE Rango and H. Wada: Mater. Trans. 44(2003) 211-213.

7) P. DE Rango, X. J. Hao, H. Ohtsuka and H. Wada: Trans. Mater. Res. Soc. Japan 28 (2003) 225-226.

8) H. Guo and M. Enomoto: Mater. Trans., JIM 41(2000) 911916.

9) M. Enomoto, H. Guo, Y. Tazuke, Y. R. Abe and M. Shimotomai: Metall. Mater. Trans. 32A(2001) 445-453.
10) K. Maruta and M. Shimotomai: J. Cryst. Growth 237239 (2002) 1802-1805.

11) M. Shimotomai, K. Maruta, K. Mine and M. Matsui: Acta Mater. 51(2003) 2921-2932.

12) Y. Xu, H. Ohtsuka and H. Wada: Trans. Mater. Res. Soc. Japan $25(2000)$ 509-512.

13) T. Watanabe, Y. Suzuki, S. Tanii and H. Oikawa: Philos. Mag. Lett. 62(1990) 9-17.

14) N. Masahashi, M. Matsuo and K. Watanabe: J. Mater. Res. 13 (1998) 457-461.

15) Y. Xu, H. Ohtsuka, S. Umezawa, K. Anak, S. Miyazaki and H. Wada: Proc. of the Fourth Int. Conf. on Recrystallization and Related Phenomena (ReX'99), Tsukuba, 13-16 July (1999) 571-576.

16) Y. Xu, H. Ohtsuka, K. Itoh and H. Wada: Journal of the Magnetics Society of Japan 24(2000) 651-654.

17) Y. Xu, H. Ohtsuka and H. Wada: Trans. Mater. Res. Soc. Japan 25 (2000) 501-504.

18) E. E. Underwood: Quantitative Microscopy, ed. by R. T. Dehoff and F. N. Rhines, (McGraw-Hill, New York, 1968) pp. 104115.

19) S. Tsurekawa and T. Watanabe: CAMP-ISIJ 17 (2004) 12101213.

20) S.Tsurekawa: personal communication. 